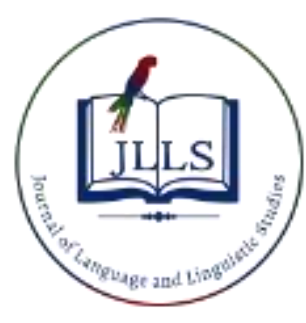

Available online at www.jlls.org

JOURNAL OF LANGUAGE AND LINGUISTIC STUDIES

ISSN: $1305-578 \mathrm{X}$

Journal of Language and Linguistic Studies, 16(2), 1070-1083; 2020

\title{
Investigation of cultural competence development processes of English translation and interpretation department students
}

\author{
Onur Köksal a 1 iD \\ ${ }^{a}$ Selçuk University, Turkey \\ APA Citation: \\ Köksal, O. (2020). Investigation of cultural competence development processes of English translation and interpretation department students \\ . Journal of Language and Linguistic Studies, 16(2), 1070-1083. \\ Submission Date:09/04/2020 \\ Acceptance Date:22/04/2020
}

\begin{abstract}
The purpose of the present research is investigating cultural competence development processes of students studying at Selcuk University Department of English Translation and Interpretation. Data of the research were collected with English Translation and Interpretation Students' Cultural Competence Development Processes Survey, developed by the researcher. The courses promoting cultural competence were identified based on the analysis of the collected data. Additionally, the present research studies whether students' cultural competence development habits varied and how they formed these habits in terms of different demographic features. At the end of the research some suggestions below were given. High school students at foreign language and other programs should be offered with clear information about the department of English Translation and Interpretation. English Translation and Interpretation students, who were born abroad, can be detected and further studies can be conducted on the reasons for their preferences of the department. Even English education starts at an earlier age in Turkey, most of the participants stated that they started to learn English between the ages 9-11. A more comprehensive study should be conducted by language educators on the reasons for this finding. In the present research, the participants were asked to self-report on their speaking, reading comprehension and writing proficiency levels. In a further study on this subject, researchers can conduct proficiency exams to define participants' levels.
\end{abstract}

(C) 2020 JLLS and the Authors - Published by JLLS.

Keywords: translation and interpretation; cultural competence; translation training; English

\section{Introduction}

There are around 40 undergraduate programs of English Translation and Interpretation at Turkish universities, including the private ones, and there are around 2060 students studying at these programs. The present research was conducted on students studying at Selcuk University Department of English Translation and Interpretation. The research investigates how cultural competence, as one of subcompetences of translation competence, is developed by students. The course program of Selcuk

\footnotetext{
${ }^{1}$ Corresponding author. Tel.

E-mail address: onurkoksal38@hotmail.com
} 
University Department of English Translation and Interpretation is also examined in the present research. The present research utilized the questionnaire technique, which is a qualitative research method.

Collected data were analysed on SPSS and tables and graphs were formed according to the analyses. Tables were interpreted in terms of the university and inferences were made based on the subjectoriented interpretations. This way, the importance attached to cultural competence by Selcuk University Department of English Translation and Interpretation students was analysed and what students do and should do for their individual learning processes were studied.

\subsection{Culture and Cultural Competent}

It is important for English Translation and Interpretation students that they learn cultural competence effectively especially during their language acquisition process (Amman, 2008). Students studying at departments offering translation training are expected to have developed their translation skills in a versatile manner within the programs they are offered with at the end of their training. For this reason, departments of English Translation and Interpretation are expected to form their programs with courses on language skills, translation skills and intercultural communication. For a more effective process, course contents should be not only theoretical but also practical. Therefore, internship practices are also of importance for students so that they can gain experience.

Translators and interpreters are expected to be able to compare, observe and use their experiences gained through these in their field. Every society has their own unique culture and their unique way using this culture in their living quarters. Culture is the combination of values, thoughts and acknowledged traditions that form individuals' behaviours within their societies (Vermeer, 1986). Therefore, the effects of culture can be seen in many areas, from tradition to family education, ethical rules of the society, individual differences, behaviours and social lives. Our premises and preferences are mostly products of the culture of the society we live in (Başçı \& Erataş, 2013). Amman (2008) defines culture as a unique product developed by the individuals consciously or unconsciously. Cultural competence is the ability to handle, use and cope with the experiences through conscious abstraction, comparison and practice (Amman, 2008).

Cultural competence is an important skill that every translator and interpreter should have, because translation and interpretation is a transfer, which is not only linguistic but also cultural (Vermeer, 1986).

Many researchers refer to cultural competence as a process of cultural transfer (Witte, 2007). Therefore, language use and cultural norms are of utmost importance for a correct translation. Today, linguistic translation theory forms the basis of the theoretical thinking that covers the most important part of the interlanguage communication (Komissarov, 1985; Cited in: İli, 2016).

\subsection{Purpose of the Research}

The purpose of the present research is defining the cultural competence development processes of students studying at Selcuk University Department of Translation and Interpretation and producing some suggestions in terms of cultural competence.

\subsubsection{Sub-problems}

1- Which high-school programs did the Selcuk University Department of English Tanslation and Interpretation students graduate from?

2- Are there any students at the department who were born abroad?

3- At what age did the students at the department start learning English?

4- What are English speaking proficiency levels of the students at the department? 
5- What are English reading comprehension proficiency levels of the students at the department?

6- What are English writing proficiency levels of the students at the department?

7- Do the students at the department have any experiences abroad?

8- What is the educational background of the mothers of the students at the department?

9- What is the educational background of the fathers of the students at the department?

10- Are there any people with a high level of English proficiency in the immediate circle of the students at the department?

11- What is the upbringing environment of the students at the department?

12- Do the students at the department use English frequently in their daily lives?

13- What do the students at the department do to learn about the English culture?

14- How often do the students at the department follow English media?

15- What difficulties do the students at the department encounter while they translate?

16- According to the students studying at the department, what courses contribute to their cultural competence development?

\section{Method}

In order to define the cultural competence development processes of Selcuk University Department of English Translation and Interpretation students, the questionnaire developed by the researcher was conducted on the students studying at Selcuk University Department of English Translation and Interpretation in 2019-2020 academic year. The questionnaire conducted on the students consists of 16 items. The total of $1361 \mathrm{st}, 2 \mathrm{nd}$ and $3 \mathrm{rd}$ year students participated in the research. Collected data were analysed on SPSS 21.00 and the findings are presented in frequencies and percentages in tables.

\section{Results}

Table 1. Highschool programs of the participants

\begin{tabular}{lcc}
\hline Program & $\mathrm{f}$ & $\%$ \\
\hline Foreign language & 92 & 67.5 \\
Equally weighted & 19 & 14 \\
Science & 8 & 6 \\
Vocational & 8 & 6 \\
Verbal & 5 & 3.6 \\
Vocational high school of Health & 4 & 2.9 \\
Total & 136 & 100 \\
\hline
\end{tabular}

As presented in Table 1, most of the Selcuk University Department of English Translation and Interpretation students graduated from foreign language programs at high schools. According to the findings, $67.5 \%$ of the students graduated from foreign language, $14 \%$ from equally-weighted programs, $6 \%$ from science programs, while $6 \%$ graduated from any department of vocational high schools, $3.6 \%$ graduated from verbal programs and $2.9 \%$ graduated from any department of vocational school of health. 
Table 2. Country of birth of participants

\begin{tabular}{lcc}
\hline Country of birth & $\mathrm{f}$ & $\%$ \\
\hline Turkey & 129 & 94.8 \\
Netherlands & 4 & 3.0 \\
Germany & 3 & 2.2 \\
Total & 136 & 100 \\
\hline
\end{tabular}

As in Table 2, most of the Selcuk University Department of English Translation and Interpretation students were born in Turkey. According to the findings, $94.8 \%$ of the students were born in Turkey, $3 \%$ were in Netherlands and $2.2 \%$ were born in Germany.

Table 3. Age range for participating students starting to learn English

\begin{tabular}{lcc}
\hline Age range & $\mathrm{f}$ & $\%$ \\
\hline 0-2 years & 1 & 0.7 \\
3-5 years & 7 & 5.2 \\
6-8 years & 20 & 14.7 \\
9-11 years & 88 & 64.7 \\
12-14 & 12 & 8.8 \\
15-17 years & 7 & 5.2 \\
18 years and older & 1 & 0.7 \\
Total & 136 & 100 \\
\hline
\end{tabular}

As presented in Table 3, most of the Selcuk University Department of English Translation and Interpretation students started to learn English between the ages 9-11. According to the findings, $64.7 \%$ of the started between ages $9-11,0.7 \%$ between $0-2,5.2 \%$ between $3-5,14.7 \%$ between $6-8,8.8 \%$ between $12-14,5.2 \%$ between $15-17$ and $0.7 \%$ when they were 18 years old or later.

Table 4. English speaking proficiency level of participating students (CEFR)

\begin{tabular}{lccc}
\hline $\begin{array}{l}\text { English } \\
\text { levels }\end{array}$ & speaking & proficiency & $\%$ \\
\hline A2 & 5 & 3.7 \\
B1 & 18 & 13.2 \\
B2 & 53 & 39 \\
C1 & 47 & 34.6 \\
C2 & 13 & 9.5 \\
Total & 136 & 100 \\
\hline
\end{tabular}


As presented in Table 4, speaking proficiency of most of the Selcuk University Department of English Translation and Interpretation students (39\%) is at B2 level. As for the other students, 3.7\% are at $\mathrm{A} 2$ level, $13.2 \%$ are at $\mathrm{B} 1$ level, $34.6 \%$ are at $\mathrm{C} 1$ level and $9.5 \%$ is at $\mathrm{C} 2$ level.

Table 5. English reading proficiency level of participating students (CEFR)

\begin{tabular}{|c|c|c|}
\hline $\begin{array}{l}\text { English reading } \\
\text { levels }\end{array}$ & $\mathrm{f}$ & $\%$ \\
\hline A2 & 1 & 0.7 \\
\hline B1 & 6 & 4.4 \\
\hline B2 & 24 & 17.7 \\
\hline $\mathrm{C} 1$ & 79 & 58.1 \\
\hline $\mathrm{C} 2$ & 26 & 19.1 \\
\hline Total & 136 & 100 \\
\hline
\end{tabular}

As presented in Table 5, reading comprehension proficiency of most of the Selcuk University Department of English Translation and Interpretation students (58.1\%) is at $\mathrm{C} 1$ level. As for the other students, $0.7 \%$ are at $\mathrm{A} 2$ level, $4.4 \%$ are at $\mathrm{B} 1$ level, $17.7 \%$ are at B2 level and $19.1 \%$ is at C2 level.

Table 6. English writing proficiency level of participating students (CEFR)

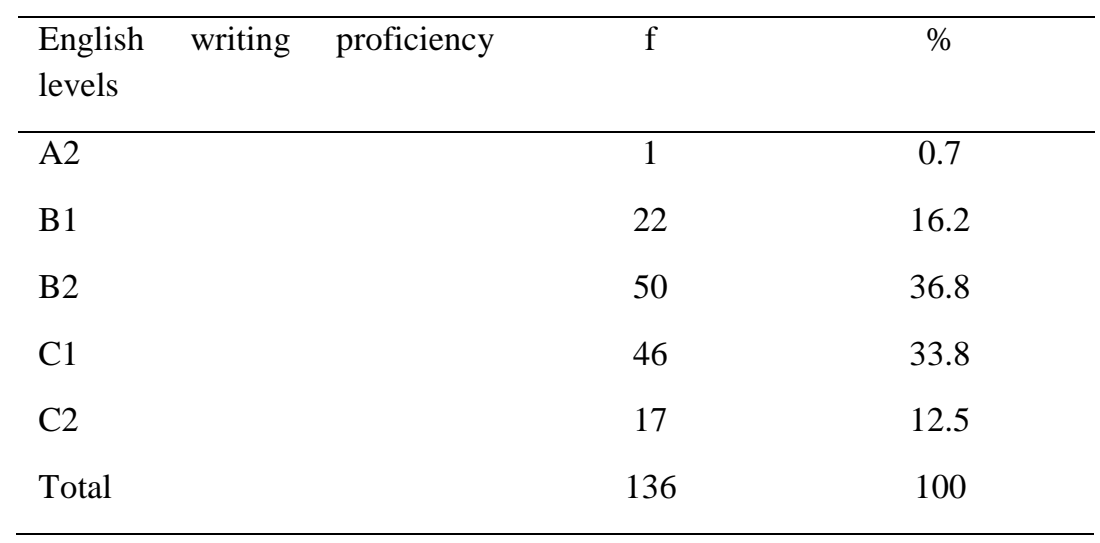

As presented in Table 6, writing proficiency of most of the Selcuk University Department of English Translation and Interpretation students (36.8\%) is at B2 level. As for the other students, $0.7 \%$ are at A2 level, $16.2 \%$ are at $\mathrm{B} 1$ level, $33.8 \%$ are at $\mathrm{C} 1$ level and $12.5 \%$ is at $\mathrm{C} 2$ level.

Table 7. Participants' experiences abroad

\begin{tabular}{lcc}
\hline Experiences abroad & $\mathrm{f}$ & $\%$ \\
\hline Yes & 39 & 28.70 \\
No & 97 & 71,30 \\
Total & 136 & 100 \\
\hline
\end{tabular}


As presented in Table 7, most of the Selcuk University Department of English Translation and Interpretation students (71.3\%) haven't had any experiences abroad. The rest, $28.7 \%$ have had experiences abroad.

Table 8. Educational background of participants' mothers

\begin{tabular}{lcc}
\hline $\begin{array}{l}\text { Educational background } \\
\text { mothers }\end{array}$ & of & f \\
\hline No formal education & 1 & 0.7 \\
Primary school graduate & 34 & 25 \\
Secondary school graduate & 31 & 23,1 \\
High school graduate & 36 & 26.6 \\
BA degree & 31 & 23,1 \\
MA degree & 1 & 0.7 \\
PhD degree & 2 & 1.43 \\
Total & 136 & 100 \\
\hline
\end{tabular}

As presented in Table 8, mothers of most of the Selcuk University Department of English Translation and Interpretation students (26.6\%) are high school graduates. As for the rest, mothers of $0.7 \%$ haven't received any formal education, $25 \%$ have primary school diplomas, $23.1 \%$ secondary school diploma, 23.1\% BA degrees, $0.7 \%$ MA degrees and $1.43 \%$ have $\mathrm{PhD}$ degrees.

Table 9. Educational background of participants' fathers

\begin{tabular}{|c|c|c|}
\hline $\begin{array}{ll}\text { Educational background of } \\
\text { fathers }\end{array}$ & $f$ & $\%$ \\
\hline No formal education & 1 & 0.7 \\
\hline Primary school graduate & 19 & 13.9 \\
\hline Secondary school graduate & 16 & 12.1 \\
\hline High school graduate & 36 & 26.4 \\
\hline BA degree & 59 & 43.3 \\
\hline MA degree & 2 & 1.4 \\
\hline $\mathrm{PhD}$ degree & 3 & 2.2 \\
\hline Total & 136 & 100 \\
\hline
\end{tabular}

As presented in Table 9, fathers of most of the Selcuk University Department of English Translation and Interpretation students (43.3\%) hold BA degrees. As for the rest, fathers of $0.7 \%$ haven't received any formal education, $13.9 \%$ have primary school diplomas, $12.1 \%$ secondary school diploma, $26.4 \%$ high school diplomas, $1.4 \%$ MA degrees and $2.2 \%$ have $\mathrm{PhD}$ degrees.

Table 10. Having someone with a high level of English proficiency in the immediate circle

\begin{tabular}{lcc}
\hline $\begin{array}{l}\text { Someone with a high level of } \\
\text { English proficiency in the }\end{array}$ & $\mathrm{f}$ & \\
immediate circle & 80 & 58.8 \\
\hline Yes & 56 & 41.2 \\
No & 136 & 100 \\
Total & & \\
\hline
\end{tabular}


As presented in Table 10, most of the Selcuk University Department of English Translation and Interpretation students (58.8\%) have someone with a high level of English proficiency in their immediate circles, while the rest, $41.2 \%$ don't have someone with a high level of English proficiency in their immediate circles.

Table 11. Upbringing environment pf participants

\begin{tabular}{lcc}
\hline Upbringing environment & $\mathrm{f}$ & $\%$ \\
\hline Village & 4 & 2.9 \\
Town & 3 & 2.2 \\
District & 26 & 19.2 \\
Small city & 15 & 11 \\
Big city & 88 & 64.8 \\
Total & 136 & 100 \\
\hline
\end{tabular}

As presented in Table 11, most of the Selcuk University Department of English Translation and Interpretation students $(64.8 \%)$ were raised in big cities. As for the rest, $2.9 \%$ were raised in a village, $2.2 \%$ in a town, $19.2 \%$ in districts, and $11 \%$ were raised in small cities.

Table 12. Frequency of using English in daily life

\begin{tabular}{lcc}
\hline $\begin{array}{l}\text { Frequency of using English in } \\
\text { daily life }\end{array}$ & $\mathrm{f}$ & $\%$ \\
\hline Yes, I use frequently & 69 & 50.7 \\
Yes, but partially & 60 & 44.1 \\
No, I don't use frequently & 7 & 5.2 \\
Total & 136 & 100 \\
\hline
\end{tabular}

As presented in Table 12, most of the Selcuk University Department of English Translation and Interpretation students (50.7\%) use English in their daily lives frequently. As for the rest, $44.1 \%$ use English partially and 5.2\% don't use English in their daily lives frequently.

Table 13. What participants do to learn about the English culture

\begin{tabular}{lcc}
\hline $\begin{array}{l}\text { What participant do to learn about the English } \\
\text { culture }\end{array}$ & $\mathrm{f}$ \\
\hline $\begin{array}{l}\text { Following online media sources, such as series, } \\
\text { movies and news }\end{array}$ & 94 & 69.1 \\
Making native English friends & 19 & 14 \\
Reading studies, research articles & 9 & 6.6 \\
Using the target language actively and being & 3 & 2.2 \\
exposed to it frequently & 11 & 8.1 \\
Nothing & 136 & 100 \\
Total & & \\
\hline
\end{tabular}

As presented in Table 13, most of the Selcuk University Department of English Translation and Interpretation students (69.1\%) state that they follow online media sources, such as series, movies and news to learn about the English culture. As for the rest, 14\% make native English friends, $6.6 \%$ read 
studies, research articles, $2.2 \%$ use the target language actively and expose themselves to it frequently and $8.1 \%$ do nothing to learn about the English culture.

Table 14. Participants' frequency of following English media

\begin{tabular}{lccc}
\hline Frequency of following English media & $\mathrm{f}$ & $\%$ \\
\hline $\begin{array}{l}\text { Following social media frequently } \\
\text { applications, through }\end{array}$ & 123 & 90.4 \\
Instagram, Facebook and Reddit & & \\
Following English media partially & & 1.5 \\
Following English media rarely & 2 & 1.5 \\
Not following English media at all & 3 & 2.2 \\
Total & 136 & 100 \\
\hline
\end{tabular}

As presented in Table 14, most of the Selcuk University Department of English Translation and Interpretation students $(90.4 \%)$ state that they follow social media frequently through applications, such as YouTube, Twitter, Instagram, Facebook and Reddit. As for the rest, 5.9\% state that they follow English media partially, 1.5\% follow rarely and 2.2\% state that they don't follow English media at all.

Table 15. Difficulties the participants encounter while they translate (E-T/T-E)

\begin{tabular}{lcc}
\hline $\begin{array}{l}\text { Difficulties the participants encounter while they } \\
\text { translate }\end{array}$ & f & $\%$ \\
\hline $\begin{array}{l}\text { Lack of concentration } \\
\text { Difficulty in understanding different accents / }\end{array}$ & 1 & 0.7 \\
listening comprehension & 2 & 1.5 \\
$\begin{array}{l}\text { No difficulties } \\
\text { Translation of proverbs and idioms }\end{array}$ & 14 & 1.5 \\
Lack of Turkish proficiency / Turkish grammar & 5 & 10.3 \\
knowledge & 2 & 3.7 \\
Ambiguities / typos in the source text & 16 & 1.5 \\
Long, inverted and complex/compound sentences & 11 & 11.8 \\
$\begin{array}{l}\text { Differences in structure between the source and } \\
\text { target languages / inability to translate structures }\end{array}$ & 64 & 8,1 \\
Lack of vocabulary / jargon knowledge & 15 & 47 \\
$\begin{array}{l}\text { Cultural differences between the source and target } \\
\text { languages }\end{array}$ & 4 & 11 \\
Inability to decide which translation method to & & 2.9 \\
use & 136 & 100 \\
Total & & \\
\hline
\end{tabular}

As presented in Table 15, most of the students (47\%) state that they have difficulties while translating due to lack of vocabulary / jargon knowledge. As for the rest, $0.7 \%$ state that they have lack of concentration, $1.5 \%$ have difficulties in understanding different accents / listening comprehension, $1.5 \%$ state they have no difficulties, $10.3 \%$ have difficulties in translating proverbs and idioms, $3.7 \%$ suffer from lack of Turkish proficiency / Turkish grammar knowledge, $1.5 \%$ have difficulties because of ambiguities / typos in the source text, $11.8 \%$ have difficulties in translating long, inverted and 
complex/compound sentences, $8.1 \%$ have difficulties due to differences in structure between the source and target languages / inability to translate structures, $11 \%$ suffer from cultural differences between the source and target languages, and $2.9 \%$ state that they have difficulties because of the inability to decide which translation method to use.

Table 16. The courses that participants think that develop cultural competence

\begin{tabular}{|c|c|c|}
\hline $\begin{array}{l}\text { Courses the develop cultural } \\
\text { competence }\end{array}$ & $\mathrm{f}$ & $\%$ \\
\hline $\begin{array}{lll}\text { Intercultural literature } & \text { and }\end{array}$ & & \\
\hline Culture & 62 & 45.6 \\
\hline $\begin{array}{l}\text { Listening comprehension and } \\
\text { verbal expression }\end{array}$ & 30 & 22.1 \\
\hline Western civilizations & 20 & 14.7 \\
\hline Special field translation & 15 & 11.0 \\
\hline Introduction to interpreting & 5 & 3.7 \\
\hline Literature translation & 4 & 2.9 \\
\hline Total & 136 & 100 \\
\hline
\end{tabular}

As presented in Table 16, most of the students (45.6\%) state that they think Intercultural literature and Culture course contributes to the development of their cultural competence. As for the rest, $22.1 \%$ think Listening comprehension and verbal expression, $14.7 \%$ think Western civilizations, $11 \%$ think Special field translation, 3.7\% think Introduction to interpreting and 2.9\% think Literature translation course contribute to the development of their cultural competence.

\section{Discussion}

According to the findings obtained from the present research, most of the Selcuk University Department of English Translation and Interpretation students graduated from foreign language programs at high schools. This finding of the research is in agreement with the findings of similar studies (Haldan, 2017; Çoban \& Odacığlu, 2018). The findings also indicate that students who graduate from equally weighted, science, vocational and health programs of high school also show interest in the department. Therefore, students, who are interested in foreign languages, can prefer to study at the department of English Translation and Interpretation no matter what program they study at high school. If high school students are offered with extensive information about English Translation and Interpretation departments including the cultural competence dimension, more students from both foreign language and other programs of high schools may prefer this department.

The findings on the country of birth of students show that most of the students preferring to study at this department were born in Turkey. Very few of the students were born abroad. Haldan (2017) reported in the study conducted on German Translation and Interpretation students that the number of students who were born in Germany was quite a few. According to the findings of the present research conducted on English Translation and Interpretation students, the number of students who were born abroad is not that much. The reason for this difference may be that students who were born abroad preferred other universities in other cities. A more comprehensive study can be conducted to have a better understanding of this case. 
Most of the participants of the present research started learning English between the ages of 9-11. Even the age for starting to learn foreign languages is much earlier recently in Turkey, the findings obtained from the present research show that current students didn't start learning English at that early ages. On the other hand, research shows that the earlier the age for starting to learn a foreign language is, the better is the proficiency (Kara, 2004; İlter \& Er, 2007; Çakıc1, 2010; Myles, 2010; Bekleyen, 2016). Moreover, Kuhl (2004) reports that bilingualism can be possible until age 9.

The participants of the present research were asked to indicate their English-speaking proficiency levels according to CEFR. According to the findings there are differences between students in terms of their levels of English-speaking proficiency, yet most of the students reported their levels as B2. Even students report different levels of English-speaking proficiency, it can be stated that they have a certain level of competence in speaking English. The differences in levels reported by the students may have resulted from the ages they started learning English, their upbringing environments or difference demographic features of them or their families.

The participants were also asked to report their reading comprehension levels in terms of CEFR. According to the findings, there are differences between students in terms of their levels of reading comprehension, yet most of the students reported their levels as $\mathrm{C} 1$. Even students report different levels of reading comprehension, it can be stated that they have a certain level of competence in reading comprehension. As mentioned before, the differences in levels reported by the students may have resulted from the ages they started learning English, their upbringing environments or difference demographic features of them or their families.

The participants of the present research were asked to indicate their English-writing proficiency levels according to CEFR. According to the findings there are differences between students in terms of their levels of English- writing proficiency, yet most of the students reported their levels as B2. Even students report different levels of English- writing proficiency, it can be stated that they have a certain level of competence in writing in English.

The participants of the research were asked whether they had any experiences abroad. According to the collected data, most of the students didn't have any experiences abroad. This finding is specifically interpreted as negative for students of translation and interpretation. Having been abroad is considered pretty important for students to get to know, understand and express the target culture, and adapt this understanding to both written and oral translation. Having experiences abroad has an important place in forming cultural competence. This also affects students' translation competence. Intercultural comparison abilities of students, who have been abroad, are better than those, who haven't, because individuals can learn the target culture by living it abroad, even partially (Çoban, Titrek, \& Saygilı, 2018).

The participants of the present research were asked about the educational background of their parents. Educational background of parents is important, since they can form and guide the education of their children. This also affects students' cultural competence dimensions. According to findings, mothers of most of the students have high school diplomas, while fathers of most hold BA degrees. Sophistication and being cultured levels of parents play an important role in sophistication and acculturation processes of their children, especially at the beginning (Haldan, 2017).

Participants of the present research were asked whether they anyone with a high level of English proficiency in their immediate circle, who can help them in learning the target language and target culture. According to the obtained findings, most of the students have someone with a high level of English proficiency in their immediate circle. Toury (1995) and Nabavi (2012) report that what individuals learn in their social living environments, and their interactions with other individuals have a very important effect on their cultural and social development processes. 
Another question the participants were asked to answer within the present research was about their upbringing environment. According to the findings, most of the students were raised in big cities. Many factors, such as the environment students were raised in, socio-cultural and socio-economic conditions of the environment, communication styles and levels between individuals in that environment, and the educational backgrounds of these individuals have an important effect on individuals' cultural competence (Holz-Mänttäri, 1986; Ergün, 2012).

The participants were asked whether they used English frequently in their daily lives. According to the findings, most of the students use English frequently in their daily lives. The frequency of the usage of the target language and its use in daily life play an important role in the development of the four language skills. Progress in these language skills is almost impossible with just theoretical training. many researchers have emphasized the importance of living the target language in language learning (Haldan, 2017).

In order to define the methods that students utilize in their cultural competence development progress, the participants were asked what they did to learn English culture. Most of the students reported that they followed online media sources, such as series, movies and news. In the process of learning a language, learning daily developments from up-to-date sources can contribute to the learning of the current target language and cultural competence. Some other participants reported that they made native friends, did research, read research articles, used the target language actively and exposed themselves to the language. These findings show that students acquire the cultural dimension of the target language from up-to-date sources as well. Additionally, we can infer that students are open to cultural regeneration.

Another item in the questionnaire conducted on the participants was about the difficulties students encountered with while they made translation, both oral and written (E-T/T-E). Most of the students state that they have difficulties while translating due to lack of vocabulary / jargon knowledge. Rest of the students reported that they had lack of concentration, had difficulties in understanding different accents / listening comprehension, had difficulties in translating proverbs and idioms, suffered from lack of Turkish proficiency / Turkish grammar knowledge, had difficulties because of ambiguities / typos in the source text, had difficulties in translating long, inverted and complex/compound sentences, had difficulties due to differences in structure between the source and target languages / inability to translate structures, suffered from cultural differences between the source and target languages, and had difficulties because of the inability to decide which translation method to use. According to this findings, contents of the courses offered to the students should include focus on vocabulary and terminology.

Finally, the participants were asked about the courses they thought to contribute to their cultural competence development. According to the findings, most of the students think that Intercultural literature and Culture course contributes to the development of their cultural competence. According to the rest, listening comprehension and verbal expression, Western civilizations, Special field translation, Introduction to interpreting and Literature translation courses contribute to the development of their cultural competence. This finding shows that the programs of English Translation and Interpretation departments include courses that aim at developing language acquisition and cultural competence (Eruz, 2008). In accordance with these opinions of the students, faculty members teaching those courses need to be very careful about the cultural focus of these courses. They need to choose and use clear and comprehensible materials and terminology in order to present cultural differences. The students come from different cultural backgrounds. Therefore, they need to be extra attentive on cultural comparisons and cultural transfer. In this process, students are expected to be open and ready for the acculturation process. Faculty members are the ones who can make this possible. 


\section{Conclusion}

\subsection{Suggestions}

1. High school students at foreign language and other programs should be offered with clear information about the department of English Translation and Interpretation.

2. English Translation and Interpretation students, who were born abroad, can be detected and further studies can be conducted on the reasons for their preferences of the department.

3. Even English education starts at an earlier age in Turkey, most of the participants stated that they started to learn English between the ages 9-11. A more comprehensive study should be conducted by language educators on the reasons for this finding.

4. In the present research, the participants were asked to self-report on their speaking, reading comprehension and writing proficiency levels. In a further study on this subject, researchers can conduct proficiency exams to define participants' levels.

5. International events should be organized and held for English Translation and Interpretation department students to introduce them with other cultures, and enable them to visit countries abroad.

6. Studies should be conducted on new methods and techniques to enable students' cultural competence development.

7. Studies can be conducted to define problems and limitations in students' cultural competence development processes, and arrangements can be made in education programs of English Translation and Interpretation departments according to the findings obtained from these studies.

8. New courses to develop cultural competence of students can be included in the programs of English Translation and Interpretation departments.

9. Panels, seminars, or workshops can be organized in order to increase the effectiveness of the faculty members teaching courses that contribute students' cultural competence.

\subsection{Limitations of the research}

1. The present research is limited to 1361 st, 2nd and 3rd year students studying at Selcuk University Department of English Translation and Interpretation.

2. Since there are no 4th year students at the department yet, the data set doesn't include any data from 4th year students.

\section{Ethics Committee Approval}

The author(s) confirm(s) that the study does not need ethics committee approval according to the research integrity rules in their country (Date of Confirmation: April 06, 2020).

\section{References}

Amman, M. (2008). Akademik çeviri eğitimine giriş. (D. Ekeman, Trans.). İstanbul: Multilingual.

Başcı, N. H. ve Erataş, F. (2013). Kültür Farklılıkları Ekseninde Girişimcilik Anlayışındaki

Değişimler ve Yabancı Girişimcilik Anemon. Muş Alparslan Üniversitesi Sosyal Bilimler Dergisi, $1(1), 155-171$. 
Bekleyen, N. (2016). Çocuklara Yabancı Dil Öğretimi. Ankara: Anı Yayıncılık.

Çakıcı, D. (2010). Parents' and English language teachers' views about early foreign language education in Turkey. Participatory Educational Research, 1,33-42.

Çoban, F. ve Odacıoğlu, C. M. (2018). Çeviribilim Veya Mütercim Tercümanlık Mezunlarının Çeviri Piyasasında Karşılaştıkları Sorunlar: Türkiye Örneği. In F. Çoban \& M. C. Odacıoğlu (Eds.), Çevirmen Psilolojisi (pp. 111-142). Ankara: Gece Akademi.

Çoban, F., Titrek, O. ve Saygıll, M. ( 2018). Analysis of Translation Students' Emotional Intelligence, Cultural Intelligence And Personality Traits in Terms Of Their Sexes In F. Çoban \& M. C. Odacioğlu (Eds.), Çevirmen Psilolojisi (pp. 143-160). Ankara: Gece Akademi.

Ergün, M. (2012). Eğitim Sosyolojisi Çocukların Sosyalleşmesine Sosyal Tabakaların Etkisi. Retrieved from https://pirtuketevayi.files.wordpress.com/2012/04/egitim-sosyolojisi.pdf

Eruz, S. (2008) Akademik Çeviri Eğitimi Çeviri Amaçlı Metin Çözümlemesi. İstanbul: Multilingual.

Haldan, A. (2017) Almanca Mütercim Tercümanlık Bölümü Öğrencilerinin Kültür Edinci Geliştirme Alışkanlıkları. Turkısh Academıc Research Review, 2(3), 69-88.

Holz-Mänttäri, J. (1986) Translatorisches Handeln.-theoretisch fundierte Berufsprofile. In: M.SnellHornby (Eds.), Übersetzungswissenschaft-Eine Neuorientierung. Zur Integrierung von Theorie und Praxis (pp.348-374). Tübingen/Basel: Francke.

İlter, B. ve Er, S. (2007) .Erken yaşta yabancı dil öğretimi üzerine veli ve öğretmen görüşleri. Kastamonu Ë̆itim Dergisi, 15(1),21-30.

Kara, Ş. (2004). Ana dil edinimi ve erken yaşta yabanc1 dil öğretimi. Uludağ Üniversitesi Eğitim Fakültesi Dergisi, 17(2), 295-314.

Komissarov, V. N. (1985). Training professional translators: the role of translation theory, Xth World Congress of FIT. Proceedings (309- 314). Wien. (G.İli, 2016, Trans.) Karatekin Edebiyat Fakültesi Dergisi (KAREFAD) 4(1), 91-102 .

Kuhl, P. K. (2004). Early language acquisition: cracking the speech code. Nature reviews neuroscience, 5(11), 831-843.

Myles, F. (2010). The development of theories of second language acquisition. Language Teaching, 43(3), 320-332

Nabavi R. T. (2012). Bandura's social learning theory \& social cognitive learning theory. Retrieved from https://www.researchgate.net/publication/267750204_Bandura's_Social_Learning_Theory_Social_ Cognitive_Learning_Theory

Toury, G. (1995). Descriptive Translation Studies and Beyond. Amsterdam: John Benjamins Publishing Company.

Vermeer, H. J. (1986). Übersetzen als kultureller Transfer. In M. Snell- Hornby (Eds.) Übersetzungswissenschaft - Eine Neuorientierung. Zur Integrierung von Theorie und Praxis (pp. 30 - 53). Tübingen: Francke.

Witte, H. (2007). Die Kulturkompetenz des Translators. Tübingen: Stauffenburg. 


\section{İngilizce mütercim tercümanlık bölümü öğrencilerinin kültür edinci gelişme sürecinin incelenmesi}

\section{$\ddot{O} z$}

Bu araştırma Selçuk Üniversitesinde öğrenim gören İngilizce Mütercim Tercümanlık bölümü öğrencilerinin kültür edinci diğer bir ifade ile kültür yetisi geliştirme süreçlerini incelemek amacıyla gerçekleştirilmiştir. Araştırmada veri toplama aracı olarak araştırmacı tarafından hazırlanmış olan İngilizce Mütercim Tercümanlık Bölümü Öğrencilerinin Kültür Edinci Geliştirme Süreci Anketi kullanılmıştır. Elde edilen veriler incelendikten sonra bölümdeki kültür edincini destekleyen dersler belirlenmiştir. Ayrıca öğrencilerin kültür edinci geliştirme alışkanlıklarının farklı olup olmadığı ve bu alışkanlıklarını nasıl kazandıkları farklı demografik özelliklerle ele alınmıştır. Araştırma sonunda aşağıda yer alan bazı öneriler yapılmışır. Lise kademesinde yabancı dil bölümünde ve diğer bölümlerde okuyan öğrencilere İngilizce Mütercim Tercümanlık bölümleri çok iyi bir şekilde anlatılıp tanıtılmalıdır. İngilizce Mütercim Tercümanlık bölümlerinde okuyan yurt dışı doğumlu öğrenciler tespit edilip üniversite ve bölüm tercihlerindeki sebepler üzerine daha geniş örneklemli bir çalışma yapılabilir. Türkiye'de daha erken yaşlarda İngilizce öğretimi başlamasına rağmen araştırmaya katılan öğrencilerin çoğu İngilizceyi 9-11 yaş aralıklarında öğrenmeye başladıklarını ifade etmişlerdir. Bunun sebepleri üzerine dil eğitimcileri tarafından çok geniş kapsamlı bir çalışma yapılmalıdır. Öğrencilere İngilizce konuşma, okuduğunu anlama ve yazma düzeylerini kendilerinin belirlemeleri istenmiştir. Bu konu ile ilgili yapılacak yeni bir çalı̧̧ada öğrencilere bu düzeylerini belirleyecek sınavlar yapılıp bu düzeyler araştırmacılar tarafından belirlenebilir.

Anahtar sözcükler: mütercim tercümanlık; kültür edinci; çeviri öğretimi; İngilizce

\section{AUTHOR BIODATA}

Onur Köksal works as an as an associate professor at Deparment of Translation and Interpretation at Selçuk University. 